\title{
The Bouquet'
}

\author{
Niilo Virkki2
}

\section{INTRODUCTION}

The bouquet of meiocytes has been a puzzle ever since the first; luxuriant description and coining of the term in 1900 (15). A polarized arrangement of chromosomes in intermitotic cells is common, and has been observed in detail by many authors from Rabl (54) to Fox (21). But in the Rabl-orientation, which arises in telophase as a consequence of mitotic orientation of daughter chromosomes, centromeres of all chromosomes point towards the centrosome, the telomeres remaining indifferent, whereas in the bouquet, telomeres are polarised towards the centrosome, the centromeres remaining indifferent. What might be the powerful reason that changes the role of centromeres and telomeres just in the meiotic prophase, and how is this change brought about?

An attempt is made in the following to answer these questions.

\section{SHIFTS IN MUTUAL POSITION OF CELL ORGANELLES}

The last part of the question already has been answered by early authors (see Wilson, 71, p. 568) who described a rotation of $180^{\circ}$ of the nucleus or its contents after the last gonial mitosis. Capability of rotating of the interphasic and prophasic nucleus is beyond doubt $(26,29)$. The centrosomes, on the other hand, are motile organelles and capable of migrating from the centromeric to the telomeric pole of the nucleus. Such a migration has been indeed postulated (28). A mitochondrial mass observed circulating around the nucleus of living grasshopper spermatocytes (4) undoubtedly contained the centrosome. A centrosome equivalent attached to the nuclear membrane may move the entire nucleus in some fungi $(24,72)$. Motility of centrioles exceeds this: Attracted by the future oocyte, they migrate from cystocytes to it, along the fusomes of the cystoblast cluster (44).

Observations in vitro of definitive spermatogonia of Oedionychine fleabeetles show that fusomes of the second and later synchronous mitoses migrate along an arc of $180^{\circ}$ on the cell surface, in order to join directly, without a cytoplasmic interruption, the main fusomal rosette, the centrofusome (28, fig. 1). Provided that there is a contact between telomeres, centrosome, and fusome mouth, migration of the fusome could bring about

1 Manuscript submitted to Editorial Board December 12, 1973.

a Cytogeneticist, Agricultural Experiment Station, Mayagüez Campus, University of Puerto Rico, Río Piedras, P.R. 
turning-around by $180^{\circ}$ of one of the daughter nuclei. Such a contact has been indeed suggested by Hirschler (28), whose bouquet hypothesis proposes a direct link of telomeres with the spindle rest of the last premeiotic mitosis. There is some new evidence in favor of this hypothesis: pulling from the fusome may draw the chromosomal contents out of a bouquet nucleus, and separate the gelic core (with centrioles) of the idiosome ${ }^{3}$ from its coat of mitochondria and Golgi apparatus (66, fig. 1, F). Also, there are mysterious invisible links, recognizable by micromanipulation, between the late anaphasic chromosomes (20). The alternative that telomeres may migrate actively along the nuclear membrane towards the extranuclear polarizing agent, is not ruled out yet.

\section{FUSOMES-AN INTERCOM SYSTEM}

The fusomes form a sort of intercom system facilitating an equal development and synchronous division in the cells involved $(18,47,58)$. A centrofusome is more efficient in this respect than a system in which the cells are intercalated between fusomes. Thus in the cystoblast cluster of Drosophila, where the fusomes do not migrate, the cells differentiate both morphologically and functionally (32). The synchrony of division is lost when trophocytes stop multiplying, leaving the oocyte alone with a future of divisions. The synchrony of DNA replication is lost even earlier (33). In such a cluster, many cells come to share more than one fusome. In some beetles, bouquet forms in all cells of the cluster, not only in the oocyte (55). Multifusomal cells do not have divided bouquets; if the polarisation is towards the fusomes, there must be one preferred fusome for it. The functional rank of the fusomes varies indeed depending on their age and location in the cystoblast cluster. Where the bouquet is limited to the oocyte or the two pro-oocytes, it seems thus that the centrosome and the telomeres become polarised towards the most important fusome mouth in each cell, or in each cluster.

\section{BOUQUET AND THE MEIOTIC MECHANICS}

Which ever of these organelles moves in a young meiocyte, and in which ever order, the end result of importance is that the telomeric pole of the nucleus, the fusome mouth, and the idiosome become juxtaposited and remain so until the beginning of diplotene.

The cytogenetic significance of the bouquet has been seen in its putative role as a device that facilitates pairing of homologous chromosomes and

$s$ This old and apparently vacant term is used here to specify the early prophasic activity center of meiocyte cytoplasm, containing a centrosome with gelated spindle proteins and microtubuli, Golgi apparatus, mitochondria, and, optionally, the centrioles. 


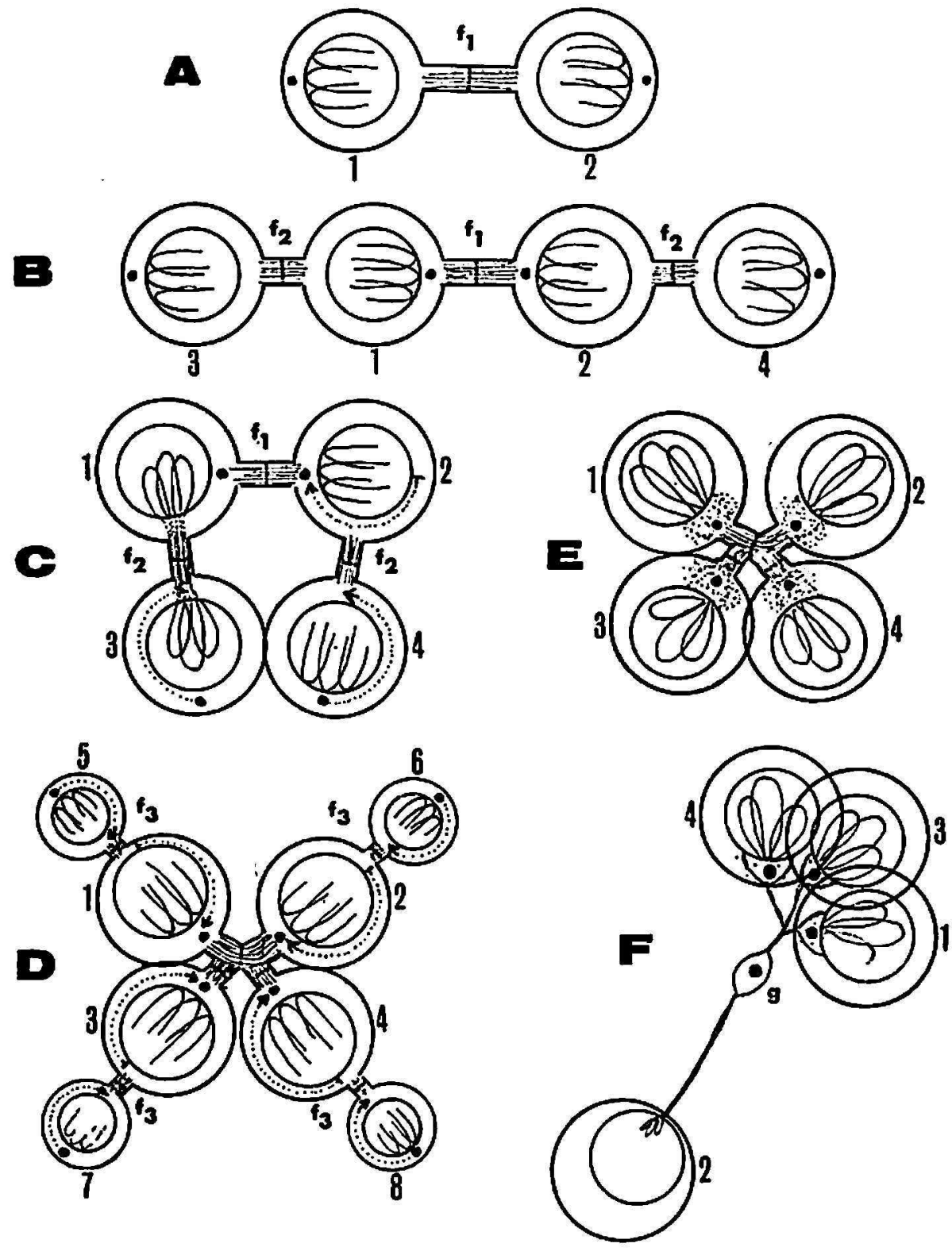

Frg. 1, A to F.-Structure and formation of a cluster of four spermatocytes in Oedionychine fleabeetles: A, First telophase of definitive (encysted) spermatogonia. Cells 1 and 2: Rabl-orientation of chromosomes to centrosomes; primary fusome $\left(f_{1}\right)$ with middle plate and spindle rest. $B$, Second telophase. Cells 3 and 4 added. New Rabl-orientation, two new fusomes $\left(f_{2}\right)$. C, Migration of secondary fusomes $\left(f_{2}\right)$ towards the primary one $\left(f_{1}\right)$, to form a centrofusome. To attain the bouquet arrangement as seen in E, orientation of nuclei and/or centrosome must change. Probable alternatives: a) Telomeres attached to fusome (cell 1 and 3). Migration of $f_{2}$ turns the nucleus of cell 1 until attachment between telomeres, centrosome, and $f_{1}$ is established; both fusomes $f_{2}$ continue migrating until they meet the mid-plate region of $f_{1}$. In cell 3 , only the centrosome migrates (arrow). b) Active polarisation of telomeres (cells 2 and 4). In cell 2 , the nucleus turns $180^{\circ}$ (arrow); in cell 4 , the centrosome migrates $180^{\circ}$ (arrow). The telomeres polarise towards idiosome. For clarity, these changes are presented here, although they may be limited to the last premeiotic telophase and interphase. $D$, Third and last telophase of definitive spermatogonia. The unequal mitosis has produced tertiary fusomes $\left(f_{8}\right)$ and small cells $5,6,7$ and 8 . Before 
affects localization of chiasmata and translocations $(11,39)$. As a rule, the pairing of homologous chromosomes begins at the telomeres attached to the nuclear membrane. This supposedly affects the genetic recombination favoring proterminal chiasmata. Polarisation of telomeres on a restricted area of nuclear membrane is supposed to help in assorting out of the homologues, but assuming that the chromosomes are randomly distributed in the nucleus prior to the bouquet (but see below), it is surprising that interlocking bivalents are as rare as they are. The bouquet is by no means a prerequisite for pairing. Although it is to be expected that the bouquet is more common than the records show, bouquet-less meioses evidently do exist $(11,39,71)$.

\section{SYSTEMS OF FUNCTION AND SEGREGATION OF CHROMOSOMES IN PRO-, "MESO"-, AND EUKARYOTA}

The observations of classical cytology have been unable to resolve the bouquet puzzle. Some new data may help in putting the bouquet in its proper place. We must consider three series of evidence:

1. In Prokaryota, the "chromosome" is a loop of practically nude double helix of DNA, forming one replicon, and attached to the cell wall (or its cytoplasmic component) by its initiator and replicator proteins $(30,31,35$, $36,50,57)$. Not further complexed by proteins, the chromosome does not undergo any contraction cycles in relation to cellular division. When the chromosome has been replicated, the sister loops are distributed to daughter cells by expansion and subsequent cleavage of the cell wall (fig. 2, A). Thus control of segregation is an obvious reason for the attachment of the chromosome to a determined zone of the cell wall, but an additional reason may be that proximity to the extracellular environment, and to the peripheral zone of reduction-oxidation reactions of the cell, are important for the proper function and replication of the chromosome.

2. In certain Ascomycetes and Basidiomycetes, where the nucleus is already present, there is an extranuclear body, resembling a centrosome without centrioles $(25,26,38,42)$. Girbardt (26) prefers to call it "kinetochore equivalent" ( $\mathrm{KCE})$, because it takes care of chromosome distribution to daughter nuclei. The chromosomes are permanently attached to it, prob-

the latter degenerate, their fusomes migrate to the common centrofusome and may produce bouquets by the method a) (of C); the alternative b) (of C) is suggested here by arrows. E, Contents of a prophasic spermatocyst: 4 fusomally interconnected spermatocytes, each having a bouquet polarised towards an idiosome-fusome complex. F, Stretching the centrofusome may draw mitochondria out from idiosome (cells 1,3 and 4), and, finally, the centrosomal gel body (g) and even chromosomes out of the cell (cell 2). (Drawing according to unpublished and published $(65,66,67)$ observations of the author.) 

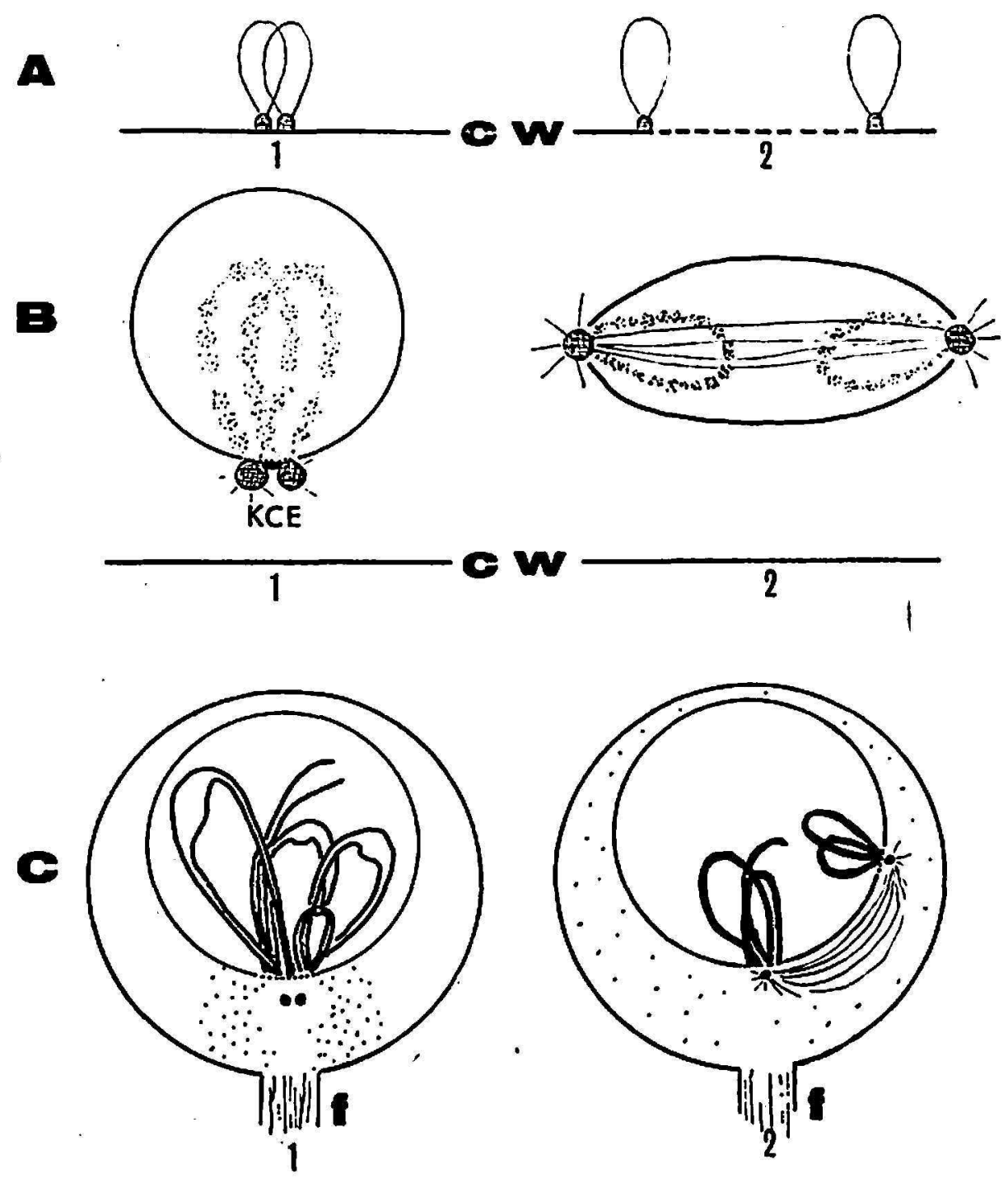

Fra. 2, A to C.-Comparable cases of attachment of chromosome ends to the limiting membrane and/or to extranuclear spindle device, with subsequent segregation phenomena. Simplified pictures drawn on an arbitrary scale, $\mathrm{cw}=$ cell wall, $f=\mathrm{fu}$ some. A 1, Just replicated bacterial chromosome attached to cell wall by special proteins. A 2, Segregation by expansion of cell wall. B 1, Just replicated chains of compound chromosome of Polystictus, attached through pores of nuclear membrane to a bipartite "Kinetochore equivalent" (KCE), which organises microtubuli. B 2, KCE divides and sinks into the nucleus, forming a partly intranuclear division apparatus. Segregation by expansion of spindle, and perhaps of nuclear membrane. C 1, Zygotene bouquet: telomeres of pairing chromosomes attached through nuclear pores to idiosomal gel containing two centrioles and continuing to the fusomal spindle rest. C 2, An exceptional case, in which the bouquet bivalents are being "segregated" by belated persistence of attachment to separating asters. Adjustment of nuclear membrane by flowing must be postulated thereby.

ably, through pores of the nuclear membrane. They seem to have rather incomplete cycle of condensation, and even at "metaphase" they remain characterless, like masses of points. The points may be primitive chromomeres. Girbardt thinks there might be several chromosomes encatenated to 
form a single loop. At all events, it seems the chromosomal structure has grown to be more complicated than in Prokaryota. DNA content has presumably increased, and chromosomal proteins have been added to some extent.

When the nucleus prepares for division, the KCE organises microtubular asters, then sinks into the nucleus where elongation of continuous, intranuclear microtubuli separates the two halves of $\mathrm{KCE}$ and the replicated chromosomes attached to them (fig. 2, B). Expansion of nuclear membrane may help thereby. There is obviously no involvement of chromosomes in the spindle; the centromeres have not yet evolved.

In general, a great variation in nuclear division devices is characteristic of fungi and lower Protista $(25,38,42)$. The cycle of chromosomal contraction varies from inconspicuous to a permanent semicondensation found in Dinoflagellata (34). A very variable array of centrosome equivalents has been described. Undoubtedly, all of them duplicate in prophase and organise a microtubular spindle, that may be extranuclear and central, in a channel piercing the nucleus $(34)$, intranuclear and central $(1,45,64)$, or normal, central, with breakdown of the nuclear membrane in prophase $(43,49)$. One and the same species may have divisions in which the nuclear membrane breaks down, and others, in which it persists during the division (73). Metaphase plates tend to be irregular even in organisms with normal spindle, and the congression movement of chromosomes, asynchronous. Centromeres may be present in cases closer to Eukaryota $(49,63)$, but usually attachment of the chromosomes to microtubuli is obscure. Even in presence of a spindle, the chromosomes may attach to the persisting nuclear membrane, and, in analogy with bacteria, their segregation results from expansion of the membrane and subsequent cleavage of the nucleus, assisted by elongation of the spindle.

Thus these systematically diverse primitives form a "Mesokaryote" group, which mediates between Pro- and Eukaryota in the nuclear structure and division.

3. The chromosomes of Eukaryota have a many thousand-fold amount of DNA as compared with Prokaryota. They are highly complexed with proteins, and undergo a typical condensation-decondensation cycle, related with replication and function of genome. Prevalent diploidy and separate chromosomes segregating from a metaphase plate provide an increased genetic recombination in meiosis. This is an evolutionary advance, and has been firmly established in higher organisms.

\section{SOMATOGRAMMIC ORDER AND PAIRING OF CHROMOSOMES}

The position of interphasic chromosomes in the nucleus is less free than nas been thought before. The old Rabl-orientation is certainly the basic 
pattern after mitosis, and is to be taken seriously. In addition, a growing body of data suggests that the chromosomes might be attached by telomeres to "somatogrammic" chains (the old continuous-spireme theory revisited!), in which the position of each chromosome is determined, probably always so that the homologues are adjacent to one another $(3,60,68,69)$. Furthermore, the chromosomes are attached to the nuclear membrane by their telomeres and numerous intercalary, especially heterochromatic, regions $(7,9,10,14,23,37,53)$, and the sites of attachment seem to be the nuclear pores; indeed, it has been suggested that each replicon is attached to a nuclear pore by its initiator $(46)$, and Engelhardt and Pusa $(16,17)$ proposed a press-stud like device of attachment, in which the "female" side is formed by the nuclear membrane, the "male" side being integral with the chromosome. Attachment at the nuclear pores apparently offers a direct communication of each replicon, at the molecular and even at the particulate (19) level, with the metabolically busy cytoplasm.

For an intimate pairing by synaptinemal complexes, the homologues must detach from the nuclear membrane, except if they are parallelly and very closely located there. The detachment must happen in leptotene at latest. Only the telomeres remain attached. These are juxtaposited, by any of the means mentioned at the beginning of this article, to the extranuclear idiosome, which, with its complex of centrioli, mitochondria, Golgi apparatus, and spindle precursor, is the center of the initiating meiotic activity. Polarisation of telomeres directly to this activity center undoubtedly compensates loss of the multiple attachments. The telomeric attachment is by means of nuclear pore complexes $(16,17)$ and continues firmly through the double membrane and further to the idiosomal gel and fusome. The fusome is formed around persisting microtubuli of the preceding mitosis; the microtubuli may disappear if interchange of organelles and particulate substances is the main function of the fusome $(18,47,58)$, but between spermatogonial cells and young meiocytes they persist. Formation, or polarisation, of the idiosome at the fusomal mouth ensures an intimate link with the intercom system of the centrofusome.

The affinity chain from nuclear pore complexes through the idiosomal gel body to fusomal microtubuli is not surprising if all three components are involved in an equilibrium system of the polymerised and unpolymerised microtubule precursor (tubulin). This possibility is at hand, because tubulins also are encountered in the nuclear membrane (62). Pulling from the fusome (fig. 1, F) shows not only how firm the telomeric attachment to the centrosome-spindle rest complex can be, but also lack of further chromosomal attachment to the nuclear membrane. Indeed, this last condition is supposed to distinguish a bouqueted prophase from a bouquet-less one: where the multiple attachments persist, the bouquet cannot form (48). 
In mitotic prophase, which is of much shorter duration than the meiotic one, and where no pairing occurs, the chromosomes remain attached to the nuclear membrane until its breakage, and even at metaphase, fragments of the membrane may still hang from the chromosomes $(9,61)$. Thus mitotic chromosomes enjoy their poral communication until they mature for the prometaphasic congression. In the meiotic prophase, on the contrary, pairing interrupts all poral communication, except for the telomeric one, which must now take care of the need of whole chromosomes during the indispensable syntheses that still occur in the bouquet phases: minor synthesis of DNA, essential for chiasma formation (70), synthesis of RNA (27), and synthesis of proteins needed for condensation of chromosomes (51). By the time of division of centrosome and distribution into cytoplasm of other idiosomal components, the bouquet becomes obsolete and is substituted by a new lateral association of bivalents with the nuclear membrane.

Bouquet polarisation thus closely resembles the contact of chromosomes of "Mesokaryota" with extranuclear centrosome equivalents and/or nuclear membrane. The centrosome equivalents may control not only segregation of the chromosomes but also initiation of their DNA synthesis (26). In this respect, comparison with the attachment of bacterial chromosomes to the cell wall also seems justified $(2,7,8,36,37)$.

\section{HYPOTHESIS}

The following tripartite hypothesis is thus plausible: 1 . The idiosome of Eukaryota is an evolutionary derivative of KCE-like structures. Like these, it also comprises elements necessary for the function and segregation of chromosomes.

2. The meiotic, freely recombinative distribution of homologues, characteristic of Eukaryota, requires segregation from a metaphase plate. For this purpose, new devices emerged at each chromosome: the centromeres. These too are capable of assembling microtubuli which somehow interact with the evolutionarily more ancient continuous spindle to bring about the equal distribution of homologues. The new segregation method substituted for the earlier membrane-bound ones in mitosis as well. The centrosometelomere complex has lost its role as controller of segregation; only abortive, residual trends of it are seen where polarised telomeres follow asters that are migrating to opposite poles at prometaphase (59, and fig. 2, C). The dispensability of centrosomal asters $(12,13,22,52)$ shows that they have lost much of their importance as organisers of the spindle as compared with, say, the centrosomal plaques of certain Ascomycetes (73).

3. In Eukaryota, the ancient need for chromosomal communication by telomeres with cytoplasm is enhanced in meiotic prophase because intimate 
pairing of homologues requires disruption of multiple poral attachments. Bouquet is the result.

If this interpretation is correct, first bouquets should appear among more advanced "Mesokaryota", with a distinct condensation cycle of individualised chromosomes possessing centromeres that segregate from metaphase plate. The Basidiomycetes Cyathus and Coprinus seem possible candidates according to photographs published by $\mathrm{Lu}$ (40). Diplophase arises as late as in zgyotene in these fungi: nuclear arrangements that resemble leptotenic bouquets join by their bases, and pairing proceeds immediately.

It would be interesting to know whether the attaching proteins, including telomeric proteins described by Berendes and Meyer (5), are similar in lower and higher organisms, and akin to spindle and membrane proteins.

\section{SUMMARY}

The bouquet, i.e., polarisation of chromosome ends to a restricted area of the nuclear membrane opposite to centrosome and fusomal mouth, is a standard event in meiosis of most Eukaryota. In mitosis, attachment of all chromosomes to nuclear membrane by nuclear pore complexes is maintained until the membrane breaks down: the bouquet cannot and needs not be formed. Intimate pairing of homologues by synaptinemal complexes requires detachment of chromosomes from the nuclear membrane in meiotic prophase. To compensate the loss of multiple communication with cytoplasm through nuclear pores, the telomeric pore complexes become associated directly with the extranuclear activity center, the idiosome ( $=$ centrosome surrounded by spindle precursor, mitochondria, and Golgi apparatus). Bouquet-less meiosis is probable where homologues are so close together at the nuclear membrane that they can pair intimately without being detached from the membrane.

Bouquet is comparable with Prokaryote and "Mesokaryote" systems, in which chromosomes are permanently attached to cellular or nuclear envelope and/or to centrosome equivalents for the purpose of replication, function, and segregation.

\section{RESUMEN}

El "bouquet" o ramillete, es decir, la polarización de los extremos de los cromosomas en un área restringida de la membrana nuclear opuesta al centrosoma y a la abertura fusomal, es un acontecimiento normal durante la meiosis en la mayoria del grupo Eukaryota. Durante la mitosis, la unión de todos los cromosomas a la membrana nuclear mediante complejos de poros nucleares persiste hasta que la membrana se rompe: el ramillete no puede ni necesita formarse. El intimo apareamiento de los homólogos por complejos sinaptinemales requiere la separación de los cromosomas de la membrana nuclear durante la profase meiótica. Para compensar la pérdida de 
comunicación múltiple con el citoplasma a través de poros nucleares, los complejos de poros teloméricos se asocian directamente con el centro de actividad extranuclear, el idiosoma ( = un centrosoma rodeado por el precursor de microtúbulos, los mitocondrios y el aparato Golgi). La existencia de una meiosis sin la formación del ramillete es probable cuando los homólogos están tan unidos en la membrana nuclear, que pueden aparearse sin necesidad de separarse de la membrana.

El ramillete es comparable a los sistemas Prokarioto y "Mesokarioto", en los cuales los cromosomas permanecen unidos permanentemente a la envoltura celular o nuclear y/o a los equivalentes al centrosoma para fines de duplicación, funcionamiento y segregación.

\section{LITERATURE CITED}

1. Aist, J. R., The mitotic apparatus in fungi, Ceratocystis fagacearum and Fusarum oxysporum, J. Cell Biol. 40: 120-35, 1969.

2. Alfert, M., and Das, N. K., Evidence for control of the rate of nuclear DNA synthesis by the nuclear membrane in eukaryotic cells, Proc. Nat. Acad, Sci. 63 : 123-28, 1969.

3. Ashley, T., and Wagenaar, E. B., End-to-end attachment of haploid chromosomes of Ornithogalum vireus, Canad. J. Genet. Cytol. 14: 716-7, 1972.

4. Barer, R., and Joseph, S., Phase-contrast and interference microscopy in the study of cell structure, Symp. Soc. Exp. Biol. 10: 160-84, 1957.

5. Berendes, H. D., and Meyer, G. F., A specific chromosome element, the telomere, of Drosophila polytene chromosomes, Chromosoma 25: 184-97, 1968.

6. Bleecken, S., Duplication of the bacterial cell and its initiation, J. Theor. Biol. 25 : 137-58, 1969.

7. Comings, D. E., The rationale for an ordered arrangement of chromatin in the interphase nucleus, Am. Hum. Genet. 20:440-60, 1968.

8. - and Kakefu, T., Initiation of deoxyribonucleic acid replication at the nuclear membrane in human cells, J. Molec. Biol. 33: 225-9, 1968.

9. - , and Okada, T. A., Association of chromatin fibers with the annuli of the nuclear membrane, Exp. Cell Res. 62: 293-302, 1970.

10. - and - Architecture of meiotic cells and mechanisms of chromosome pairing, Adv. Cell Molec. Biol. 2 : 310-84, 1972.

11. Darlington, C. D., Cytology, Churchill, London, 768 pp., 1965.

12. Dietz, R., Centrosomenfreie Spindelpole in Tipuliden-Spermatocyten, Z. Naturforsch. 14b: 749-52, 1959.

13. - The dispensability of the centrioles in the spermatocyte divisions of Pales ferruginea (Nematocera), Chromosomes Today 1: 161-6, 1966.

14. DuPraw, E., Macromolecular organization of nuclei and chromosomes: a folded fibre model based on whole-mount electron microscopy, Nature 206: 338-43, 1966.

15. Eisen, G., The spermatogenesis of Batrachoseps. Polymorphous spermatogonia, auxocytes, and spermatocytes, J. Morph. 17: 1-17, 1900.

16. Engelhardt, P., and Pusa, K., New substructure of chromomeres moiety of the nuclear pore complex (NPC), Scand. Clin. Lab. Invest. 29 (Suppl. 122): 53, 1972.

17. - and - Nuclear pore complexes: "Press-stud" elements of chromosomes in pairing and control, Nature 240: 163-6, 1972.

18. Fawcett, D. W., Ito, S., and Slautterback, D. B., The occurrence of intercellular bridges in groups of cells exhibiting synchronous differentiation, J. Cell Biol. 5: $453-60,1959$. 
19. Feldherr, C. M., Structure and function of the nuclear envelope, Adv. Cell Molec. Biol. 2: 273-309, 1972.

20. Forer, A., and Koch, C., Influence of autosome movements and of sex chromosome segregation in crane fly spermatocytes, Chromosoma 40: 417-42, 1973.

21. Fox, D. P. The effects of X-rays on the chromosomes of locust embryos. II. Chromatid interchanges and the organization of the interphase nucleus, Chromosoma 20 : 173-94, 1966.

22. Friendländer, M., and Wahrman, J., The spindle as a basal body distributor, J. Cell Sci. 7: 65-89, 1970.

23. Fussell, C. P., The interphase position of chromosomes in onion roottip nuclei (Abstract), J. Cell Biol. 55: 79 a, 1972.

24. Girbardt, M., Ultrastructure and dynamics of the moving nucleus, Symp. Soc. Exp. Biol. 23: 249-59, 1968.

25. - Submikroskopische Cytologie der Pilzzelle, Fortschr. Bot. 33: 19-32, 1971.

26. - Ultrastructure of the fungal nucleus. II. The kinetochore equivalent (KCE), J. Cell Sci. 9: 453-73, 1971.

27. Henderson, S. A., RNA synthesis during male meiosis and spermiogenesis, Chromosome 15: 345-66, 1964.

28. Hirschler, J., Utber den Anteil des Fusoms an dem Zustandekommen des Bukettstadiums und der bilateralen Symmetrie im tierischen Ei, Zool. Jb. 64: 514-37, 1953.

29. Hughes, A. F., The Mitotic Cycle, Butterworth, London, 232 pp., 1952.

30. Jacob, F., Brenner, S., and Cuzin, F., On the regulation of DNA replication in bacteria, Cold Spring Harbor Symp. Quant. Biol. 28: 329-48, 1963.

31. - Ryter, A., and Cuzin, F., On the association between DNA and membrane in bacteria, Proc. Roy. Soc. B 164: 267-78, 1966.

32. King, R. C., Ovarian Development in Drosophila melanogaster, Academic Press, New York and London, 227 pp., 1970.

33. —, and Burnett, R. G., Autoradiographic study of uptake of tritiated glycine, thymidine, and uridine by fruit fly ovaries, Science 129: 1,964-5, 1959.

34. Kubai, D. F., and Ris, H., Division in the dinoflagellate Gyrodinium cohni (Schiller). A new type of nuclear reproduction, J. Cell Biol. 40: 508-28, 1969.

35. Kuempel, P. L., Bacterigl chromosome replication, Adv. Cell Biol. 1: 3-56, 1970.

36. Lark, K. G., Regulation of chromosome replication and segregation in bacteria, Bact. Rev. 30: 3-32, 1966.

37. - Consigli, R. A., and Minocha, H. C., Segregation of sister chromatids in Mammalian cells, Science 154: 1,202-04, 1966.

38. Lerbs, V., and Thielke, C., Die Entstehung der Spindel während der Meiose von Coprinus radiatus, Arch. Mikrobiol. 68: 95-8, 1969.

39. Lewis, K. R., and John B., Chromosome Marker, Churchill, London, 489 pp., 1963.

40. Lu, B. C., Chromosome cycles of the basidiomycete Cyathus stercoreus (Schw.) de Toni, Chromosoma 15: 170-84, 1964.

41. - Fine structure of the meiotic chromosomes of the fungus Coprinus lagopus, Exp. Cell Res. 43: 224-7, 1966.

42. - The course of meiosis and centriole behavior during the ascus development of the ascomycete Gelasinospora calospora, Chromosoma 22: 210-6, 1967.

43. - Meiosis in Coprinus lagopus: a comparative study with light and electron microscopy, J. Cell Sci. 2: 529-36, 1967.

44. Mahowald, A. P., and Strassheim, J. M., Intercellular migration of centrioles in the germarium of Drosophila melanogaster, J. Cell Biol. 45: 306-20, 1970. 
45. Manton, I., Kowallik, K., and Stosch, H. v., Observations on the fine structure and development of the spindle at mitosis and meiosis in a marine centric diatom (Lithodesmium undulatum), J. Cell. Sci. 5: 271-98, 1969:

46. Maul, G. G., Maul, H. M., Scogna, J. E., Lieberman, M. W., Stein, G. S., Hsu, B. Y., and Borun, T. W., Time sequence of nuclear pore formation in phytohemagglutinin-stimulated lymphocytes and in He-La cells during the cell cycle, J. Cell Biol. 55: 433-47, 1972.

47. Meyer, G. F., Interzellulare Brücken (Fusome) im Hoden und im Ei-Nährzellenverband von Drosophila melanogaster, Z. Zellf. 54: 238-51, 1961.

48. Moses, M. J., Synaptinemal complex, Ann. Rev. Genet. 2: 363-412, 1968.

49. Motta, J. J., Somatic nuclear division in Armillaria mellea, Mycologia 61 : 873-86 1969.

50. Mulder, M. P., Duijn, P. v., and Gloor, H. J., The replicative organization of DNA in polytene chromosomes of Drosophila hydei, Genetica 39: 385-428, 1969.

51. Parchman, L., and Roth, T., Pachytene synaptonemal complexes and meiotic achiasmatic chromosomes, Chromosoma 33: 129-45, 1971.

52. Pickett-Heaps, J. D., The evolution of the mitotic apparatus: an attempt at comparative ultrastructural cytology in dividing plant cells, Cytobios 3: 25780, 1969.

53. Pusa, K., Diplotene repulsion and the timing of non-homologous associations, Chromosomes Today 1: 84-98, 1966.

54. Rabl, C., Ưber Zellteilung, Morph. Jb. 10: 214-330, 1885 (cited from 71).

55. Ribbert, D., and Weber, F., Homologous pairing and synaptinemal complexes in the nurse cell nuclei of Carabid ovaries, Experientia 26:800-1, 1970.

56. Robinow, C. F., and Marak, J., A fiber apparatus in the nucleus of the yeast cell, J. Cell Biol. 29: 129-51, 1966.

57. Ryter, A., Association of the nucleus and the membrane of bacteria: A morphological study, Bact. Rev. 32: 39-54, 1968.

58. Satir, P., and Gilula, N. P., The fine structure of membranes and intercellullar communication in insects, Ann. Rev. Entom. 18: 143-66, 1973.

59. Schrader, F., The spermatogenesis of the earwig Anisolabis maritima Boh. with reference to the mechanism of chromosomal movement, J. Morph. 68: 123-48, 1941.

60. Shchapova, A. I., Karyotype pattern and the chromosome arrangement in the interphase nucleus, Tsitologiya 13: 1,157-64, 1971.

61. Sprey, B., and Hasche, A., Ultrastrukturelle Veränderungen der Kernmenbran von Lepidium sativum L. in der Mitose, Cytologia 37: 721-45, 1972.

62. Stadler, J., and Franke, W. W., Colchicine-binding proteins in chromatin and membranes, Nature NB 237: 237-8, 1972.

63. Sun, N. C., and Bowen, C. C., Ultrastructural studies of nuclear division in Basidiobolus ranarum Eidam, Caryologia 25: 471-94, 1972.

64. Vickerman, K., and Preston, T. M., Spindle microtubules in the dividing nuclei of Trypanosomes, J. Cell Sci. 6: 365-83, 1970.

65. Virkki, N., Sperm bundles and phylogenesis, Z. Zellf. 101: 13-27, 1969.

66. - Contraction stage and formation of distance sex bivalent in Oedionychina (Coleoptera, Alticidae), Hereditas 71: 259-88, 1972.

67. - Spermatogonial budding in fleabeetles, Caryologia 26: 405-423, 1973.

68. Wagenaar, E., Attached chromosome ends at interphase in Allium cepa and Crepis capillaris, Canad. J. Genet. Cytol. 10: 769, 1968. 
69. - End-to-end chromosome attachments in mitotic interphase and their possible significance to meiotic chromosome pairing, Chromosoma 26:410-26, 1969.

70. Whitehouse, L. K., A theory of crossing-over by means of hybrid deoxyribonucleic acid, Nature 199: 1,034-40, 1963.

71. Wilson, E. B., The Cell in Development and Heredity, Macmillan, New York, 1,232 pp., 1928.

72. Wilson, C. L., and Aist, J. R., Motility of fungal nuclei, Phytopathology 57 : $769-$ 71, 1967.

73. Zickler, D., Division spindle and centrosomal plaques during mitosis and meiosis in some Ascomycetes, Chromosoma 30: 287-304, 1970. 